\title{
Бородин Г.В. \\ Правовая проблема соотношения кадастровой и рыночной стоимости земельного участка
}

ФГБОУ ВО «Кубанский государственный аграрный университет имени И. Т. Трубилина»

(Россия, Краснодар)

doi: $10.18411 / l j-02-2021-198$

idsp: ljournal-02-2021-198

\section{Аннотация}

В научной работе рассматривается актуальная проблема соотношения кадастровой и рыночной стоимости земельного участка, в рамках реализации права на землю. Дается понятие кадастровой и рыночной стоимости земельного участка, учитывая законодательство РФ. В ходе детального анализа правовых пробелов в земельном законодательстве в сфере соотношения и регулирования кадастровой и рыночной стоимости земельного участка были установлены проблемы и найдены пути их решения.

Ключевые слова: земельный участок, земельные правоотношения, кадастровая стоимость, рыночная стоимость, земля, объект оценки, земельное законодательство.

\section{Abstract}

The scientific work deals with the actual problem of the ratio of the cadastral and market value of a land plot, within the framework of the implementation of the right to land. the concept of cadastral and market value of a land plot is given, taking into account the legislation of the russian federation. in the course of a detailed analysis of legal gaps in land legislation in the field of correlation and regulation of cadastral and market value of land, problems were identified and ways to solve them were found.

Keywords: land plot, land legal relations, cadastral value, market value, land, object of assessment, land legislation.

Земля на сегодняшний день является экономическим стержнем земельных правоотношений и социально-экономической опорой для государства. Земельный участок обладает неисчерпаемым, универсальным потенциалам в использовании и извлечении экономической выгоды для его владельца. Земельным законодательством предусмотрены различные способы целевого использования земли, которые направлены на распоряжение определенными территориями для застройки жилых домов, проектирования подсобных построек, организация фермерского или огородного хозяйства. Владелец земельного участка имеет возможность совершать любые административные и финансовые операции в рамках закона, например: покупать или продавать землю. Но для того, чтобы земельные правоотношения полноценно могли функционировать и развиваться, необходимо устранить правовые проблемы в определении, соотношении и взаимодействии между кадастровой и рыночной стоимостью земельного участка.

Под кадастровой стоимостью понимается стоимость, установленная в результате проведения государственной кадастровой оценки или в результате рассмотрения споров о результатах определения кадастровой стоимости. Кадастровая стоимость - это стоимость объекта недвижимости определенная на основе рыночной информации, на основе усредненных данных о массовой оценке. Ее определение необходимо государству для выявления налогооблагаемой базы и выполнения ряда других регулирующих функций. На наш взгляд, исследуя развитие и современное состояние кадастровой стоимости, как вида оценочной деятельности, необходимо отметить 
потребность в тенденции развития законодательства. На современном этапе существует достаточно обширный комплекс пробелов, проблем которые представлены коллизионным противоречием, отсутствием должного правового регулирования отдельных правовых аспектов кадастровой оценки земельного участка. Были предложены различные пути, которые бы помогли решить определенные правовые проблемы. Только после модернизации и обновления законодательства реализация процедуры кадастровой оценки земельного участка будет действовать в полную законную и разумную силу.

Под рыночной стоимостью земельного участка на современном этапе правового развития понимается наиболее вероятная цена, по которой данный, индивидуальноопределенный объект оценки может быть отчужден на открытом рынке в установленных условиях законной конкуренции, когда стороны сделки действуют в рамках разумности и законности, при этом располагая всей необходимой достоверной и правдивой информацией и на величине фиксированной цены сделки не отражаются различные чрезвычайные обстоятельства. Рыночной стоимостью называется цена, с которой согласны все участники сделки, осуществляемой в условиях конкуренции на свободном рынке. На эту цену не влияют существенные обстоятельства, а процесс её установки допускается в обязательном и в добровольном порядке. С помощью этой оценки устанавливается рыночная стоимость какого-либо имущества. В широком понимании этот процесс является оцениванием имущественного права с учётом любых имеющихся ограничений. Обязательная оценка требуется в случаях, которые устанавливаются законом, а именно отчуждение недвижимости, находящейся в собственности (полностью либо частично) РФ, какого-либо субъекта федерации или муниципального учреждения. Согласно гражданскому кодексу, недвижимым имуществом считаются земельные участки, а также объекты, перенос которых возможен, но понесёт непоправимый ущерб их целевому назначению. Например: строения, участки земли, космические объекты и т.д.

Проблемы совершенствования правового регулирования рыночной стоимости земельного участка и проблемы совершенствования правового регулирования кадастровой стоимости земельного участка взаимосвязаны и требуют общего решения. На наш взгляд, необходимо устранить между основополагающими законами (Конституция, Земельный кодекс, Водный кодекс, Лесной кодекс) противоречия и пробелы, которые напрямую ведут к коллизиям. Для этого необходимо создать единую систему регулирования, которая бы нивелировала коллизионное регулирование. Также существует практика существенного занижения предлагаемой оценщиком стоимости услуг при проведении конкурса, что свидетельствует либо о некомпетентности оценщика, либо о стремлении вытеснить с рынка конкурентов за счет выполнения работ ниже себестоимости. Предлагаем исключить возможность подобного демпинга путем введение поправки в Закон № 94-Ф3, касающейся учета квалификации и репутации оценщика. А также включать в реестр недобросовестных поставщиков организации. Одной из ключевых проблем, на наш взгляд, является проблема в дифференциации рыночной стоимости и кадастровой стоимости. Этот разрыв не имеет законодательно установленных границ, именно из-за этого и возникают правоотношения, в сфере оспаривания кадастровой стоимости. Административный истец считает, что результаты государственной кадастровой оценки стоимости определенного земельного участка являются неверными и нарушают его права, что в конечном итоге приводит к обращению либо в комиссию по рассмотрению споров о результатах определения кадастровой стоимости, либо в суд. Из-за данной проблемы, суды заполнены, На данный момент комиссия по рассмотрению споров о результатах определения кадастровой стоимости при Управлении Росреестра не функционирует на должном уровне. Она должна разгружать и компетентно разрешать вопросы оспаривания государственной кадастровой оценки, её перерасчета исходя из рыночной 
стоимости земельного участка. Но на практике процент разрешенных дел крайне низок, а процент отказов в удовлетворении заявленных требований крайне высок. Комиссия по факту перенаправляет дела в суд, который с каждым годом становится все более загруженным подобной категорией дел. Предлагаем провести ряд законодательных изменений в приказ минэкономразвития России от 04.05.2012 № 263 для увеличения эффективности комиссии по рассмотрению споров о результатах определения кадастровой стоимости. Исходя из вышесказанного, можно сделать вывод о том, что необходимо провести обновление законодательства в сфере соотношения и применения кадастровой и рыночной стоимости земельного участка путем устранения вышеназванных проблем.

$$
* * *
$$

1. Об оценочной деятельности в Российской Федерации: Федеральный закон от 29.07.1998 №135-ФЗ (ред. от 03.08.2018) // Российская газета 29.07. 1998 г.

2. О размещении заказов на поставки товаров, выполнение работ, оказание услуг для государственных и муниципальных нужд: Федеральный закон от 21.07.2005 № 94-Ф3 (ред. от 30.12.2012 с изменениями, вступившими в силу с 01.01.2013) // Российская газета 21.07.2012 г.

3. Об утверждении порядка создания и работы комиссии по рассмотрению споров о результатах определения кадастровой стоимости: Приказ Минэкономразвития России от 04.05.2012 № 263 (ред. от 16.05.2013, с изм. от 26.04.2018) // Российская газета 04.05.2012 г.

4. Решение Краснодарского краевого суда от 24.05.2020 г. по делу №6a -168/2020 // СПС «КонсультантПлюс».

5. Аверьянова Н.Н. Земельное право в вопросах и ответах. М.: Проспект, 2018. 128 с.

6. Колиева А.Э., Таутиева М.Э. Расторжение односторонних договоров, как свойство фидуциарных договоров // Тенденции развития современной юриспруденции, материалы Международной заочной научно-практической конференции. 2015. С. 27-31.

7. Таутиева М.Э., Колиева А.Э. Вестник Северо-Осетинского государственного университета имени К.Л. Хетагурова // Порядок и последствия предоставления отступного по договорным обязательствам. 2011. № 4. С. 168-171.

\section{Бялт В.С. ${ }^{1}$, Лойт X.X. ${ }^{2}$ \\ К вопросу о противодействии коррупции на государственной службе Российской Федерации \\ ${ }^{1}$ Санкт-Петербургский университет МВД России \\ ${ }^{2}$ Санкт-Петербургский государственный университет аэрокосмического приборостроения \\ (Россия, Санкт-Петербург)}

doi: $10.18411 / l j-02-2021-199$

idsp: ljournal-02-2021-199

\section{Аннотация}

Статья посвящена исследованию системы мер противодействия коррупции на государственной службе Российской Федерации с точки зрения повышения эффективности ее функционирования. Авторы, анализируя нормативную правовую базу в сфере противодействия коррупционным проявлениям среди государственных служащих и практику ее применения, формулируют и обосновывают ряд выводов касательно исследуемых вопросов.

Ключевые слова: коррупция; государственная служба; противодействие коррупции; антикоррупционная политика.

\section{Abstract}

The article is devoted to the study of the system of anti-corruption measures in the civil service of the Russian Federation from the point of view of improving the efficiency of its functioning. The authors, analyzing the regulatory framework in the field of combating 